\title{
Inducers of resistance and silicon on the activity of defense enzymes in the soybean-Phakopsora pachyrhizi interaction
}

\author{
Maria Fernanda Antunes da Cruz ( $\left.{ }^{1 *}\right)$; Fabrício Ávila Rodrigues ( $\left.{ }^{2}\right)$; Leonora Rodriguez Polanco ( ${ }^{2}$ ); \\ Carmen Rosa da Silva Curvêlo (2); Kelly Juliane Telles Nascimento (2); Maurílio Alves Moreira ( ${ }^{3}$ ); \\ Everaldo Gonçalves Barros (')
}

(') Universidade Federal de Viçosa (UFV), Departamento de Biologia, 36570-000 Viçosa (MG), Brasil.

(2) UFV, Departamento de Fitopatologia, 36570-000 Viçosa (MG), Brasil.

(3) UFV, Departamento de Bioquímica e Biologia Molecular, 36570-000 Viçosa, (MG), Brasil.

(*) Corresponding author: fertunes@bol.com.br

Received: Mar. 7, 2013; Accepted: Apr. 8, 2013

\begin{abstract}
This study aimed to determine the effect of jasmonic acid (JA), Acibenzolar-S-Methyl (ASM) and calcium silicate (a source of soluble silicon, Si), on the potentiation of soybean resistance to Asian soybean rust (ASR). The ASR severity was significantly reduced on plants sprayed with ASM or supplied with Si in comparison to plants sprayed with JA or deionized water. For chitinases (CHI), significant differences in activity between non-inoculated and inoculated plants sprayed with deionized water or with ASM occurred at 72 hours after inoculation (hai), at 24 and 72 hai when sprayed with JA and at 141 hai when supplied with Si. For $\beta$-1,3-glucanases (GLU), significant differences in activity between non-inoculated and inoculated plants sprayed with deionized water occurred at 24, 48 and 141 hai, but not until 72 for plants sprayed with ASM. For phenylalanine ammonia-lyases (PAL), significant differences in activity between non-inoculated and inoculated plants occurred only for plants sprayed with ASM at 72 and 141 hai. In conclusion, the ASR symptoms can be mild on plants sprayed with ASM or supplied with $\mathrm{Si}$ and that this amelioration likely involved the defense enzymes.
\end{abstract}

Key words: Glycine max, Asian soybean rust, induction of resistance, mechanisms of host defense.

\section{Indutores de resistência e silício na atividade de enzimas de defesa na interação soja-Phakopsora pachyrhizi}

\section{Resumo}

Este estudo objetivou determinar o efeito do ácido jasmônico (AJ), do Acibenzolar-S-Metil (ASM) e do silicato de cálcio (fonte de silício solúvel, Si) na potencialização da resistência da soja à ferrugem asiática (FA). A severidade da FA foi significativamente reduzida nas plantas pulverizadas com ASM ou supridas com Si em comparação com as plantas pulverizadas com água deionizada ou A). Para a atividade das quitinases (QUI), diferenças significativas entre plantas não inoculadas e inoculadas que foram pulverizadas com água destilada ou ASM ocorreram às 72 horas após a inoculação (hai); às 24 e 72 hai para plantas pulverizadas com AJ e às 141 hai quando supridas com Si. Para $\beta$-1,3-glucanases (GLU), diferenças significativas entre plantas inoculadas e não inoculadas que foram pulverizadas com água deionizada ocorreram às 24, 48 e 141 hai, mas não ocorreram até as 72 hai para plantas pulverizadas com ASM. Para fenilalanina amônia-liases (PAL), houve diferença significativa na atividade entre plantas inoculadas e não inoculadas somente para aquelas pulverizadas com ASM as 72 e 141 hai. Em conclusão, os sintomas da FA podem ser reduzidos em plantas pulverizadas com ASM ou em plantas supridas com Si, em parte, pela participação das enzimas de defesa estudadas.

Palavras-chave: Glycine max, ferrugem asiática, indução de resistência, mecanismos de defesa do hospedeiro.

\section{INTRODUÇÃO}

Asian soybean rust (ASR), caused by the fungus Phakopsora pachyrhizi, is one of the most destructive diseases of soybean (Sinclair and Hartman, 1999). The initial symptoms of ASR are chlorosis of polygonal shape in the leaves delimited by the veins that evolve later to brown lesions where uredia containing numerous urediniospores arise (SINCLAIR and Hartman, 1999). ASR is a difficult disease to control due to the highly aggressive nature of the pathogen and the absence of cultivars with satisfactory levels of resistance (YAMANAKA et al., 2010). The greatest damage caused by ASR is the early defoliation of the plants (Li et al., 2010), which results in a reduction in the number of pods, number 
of grains per pod and total grain weight (OGLE et al., 1979). Although ASR can be preventively controlled by spraying fungicides, this practice is becoming increasingly expensive as the production costs of such fungicides rise (YorINORI et al., 2003).

General pathogen resistance can be induced through the application of jasmonic acid (JA), ethylene (ET) and salicylic acid (SA) as well by biotic agents such as plant-growth-promoting bacteria, all of which lead to the activation of numerous defense mechanisms during pathogen infection (Dong, 1998). The activation of host defense mechanisms using JA, ET and SA has been reported for cucumber, potato, rice, tobacco, and tomato (SCHweizer et al., 1998; Achuo et al., 2004; HaLim et al., 2007).

In addition to these inducers of resistance, the application of silicon $(\mathrm{Si})$ can also reduce the severity of many diseases in many plant species, mainly because it is involved in the potentiation of multiple host defense mechanisms (DATnoff et al., 2007; BRunings et al., 2009; Shetty et al., 2012). It is believed that $\mathrm{Si}$ acts as a physical barrier after being deposited under the cuticle, resulting in a cuticle-Si double layer (Yoshida et al., 1962) that can prevent or delay pathogen penetration, thereby prolonging the incubation period and even the latent period (Datnoff et al., 2007; Resende et al., 2009). Moreover, in the presence of Si, plants infected by pathogens generally exhibit increased production of phenolics and phytoalexins, increased activity of chitinases, peroxidases and polyphenoloxidases and the transcription of genes encoding for $\beta-1,3-$ glucanases, peroxidases and PR-1 (DATnoff et al., 2007) besides increased formation of papillae and callose and hydrogen peroxide deposition in the infected cells (Sнetty et al., 2012). In field experiments, foliar applications of potassium silicate reduced ASR severity (Rodrigues et al., 2009; Lemes et al., 2011).

The foliar application of inducers of resistance (JA and ASM) and the growth of soybean plants on soil amended with a soluble source of Si prior to inoculation with $P$. pachyrhizi can possibly reduce the ASR symptoms through the activation of host defense responses. The plant hormone JA and the inducer ASM operate on two separated routes that lead, respectively, to induce systemic resistance and systemic acquired resistance. On the other hand, $\mathrm{Si}$ is a mineral that after being translocated from roots to the shoots can act both as a physical barrier to avoid or delay pathogens penetration or potentiate mechanisms of defense. Based on the above information, the present study aimed to determine whether the reduction of ASR severity can be linked with an increase in the activities of defense enzymes chitinases, $\beta$-1,3-glucanases and phenylalanine amonia-liases on plants after being sprayed with JA and ASM as well as supplied with Si.

\section{MATERIAL AND METHODS}

\section{Soil amendment with silicon}

The soil type used in the experiments was a Si-deficient typical Acrustox red-yellow latosol collected at the Triângulo Mineiro savanna area and showing the following characteristics: $530 \mathrm{~g} \cdot \mathrm{kg}^{-1}$ of clay; $\mathrm{pH}$ in $\mathrm{KCl}=4.8$; $\mathrm{P}$ (Mehlich-1) $=0.5 \mathrm{mg} \mathrm{dm}^{-3} ; \mathrm{K}$ (Mehlich-1) $=13 \mathrm{mg} \mathrm{dm}^{-3}$; $\mathrm{Al}^{3+}, \mathrm{Ca}^{2+}, \mathrm{Mg}^{2+}, \mathrm{H}^{+}+\mathrm{Al}^{3+}=0.1,0.0,0.0$ and $3.8 \mathrm{cmol}_{c} \mathrm{dm}^{-3}$, respectively; base saturation $=2 \%$ and organic matter $=2.3 \mathrm{dag} \mathrm{kg}^{-1}$. The concentration of available $\mathrm{Si}$ (extraction in $\mathrm{CaCl}_{2}$ ) was $11.8 \mathrm{mg} \mathrm{dm}{ }^{-3}$. Each plastic pot (Ecovaso, Jaguariúna, SP, Brazil) was filled with $2 \mathrm{~kg}$ of air-dried, sieved $(5 \mathrm{~mm})$ soil. The calcium silicate used as the $\mathrm{Si}$ source (AgroSilício ${ }^{\circ}$, Harsco Minerais Ltda, Timóteo, Minas Gerais, Brazil) was composed of $10.5 \%$ $\mathrm{Si}, 25 \% \mathrm{Ca}$ and $6 \% \mathrm{Mg}$. The calcium silicate was incorporated into each pot at the rates of 0 and $1.75 \mathrm{~g} \mathrm{~kg}^{-1}$ of soil, which corresponded, respectively, to 0 and $0.39 \mathrm{~g}$ of elemental Si per $\mathrm{kg}$ of soil. Calcium carbonate $(40 \%$ $\mathrm{Ca}$, Sigma-Aldrich, São Paulo, Brazil) and magnesium carbonate $\left(\mathrm{MgCO}_{3}\right.$, Sigma-Aldrich, São Paulo, Brazil) were added at the rates of 1.19 and $0.48 \mathrm{~g} \mathrm{~kg}^{-1}$ of soil, respectively, to the pots that did not receive $\mathrm{Si}$ in order to equilibrate the amounts of $\mathrm{Ca}$ and $\mathrm{Mg}$ in this treatment with the amounts present in the pots that received $1.75 \mathrm{~g}$ of calcium silicate. The amounts of $\mathrm{Ca}$ and $\mathrm{Mg}$ among the treatments were fixed at 0.27 and $0.05 \mathrm{~g}$, respectively, per pot. The soil in each pot was incubated for 60 days with an approximate humidity of $65 \%$.

\section{Plant growth and treatments}

Soybean seeds from cultivar MG/BR 46 (Conquista), susceptible to $P$. pachyrhizi, were surface sterilized in $10 \% \mathrm{NaOCl}(\mathrm{v} / \mathrm{v})$ for 5 minutes, rinsed in sterilized water for 3 minutes and sowed at the rate of four seeds per pot. Five days after emergence, each pot was thinned to two plants. Soil in each pot was fertilized before sowing with $1.63 \mathrm{~g}$ of calcium phosphate per $\mathrm{kg}$ of soil and with $30 \mathrm{~mL}$ of a nutrient solution containing, in $\mathrm{g} \mathrm{L}^{-1}, 6.4 \mathrm{KCl}$, $3.48 \mathrm{~K}_{2} \mathrm{SO}_{4}, 5.01 \mathrm{MgSO}_{4} .7 \mathrm{H}_{2} \mathrm{O}, 2.03\left(\mathrm{NH}_{2}\right)_{2} \mathrm{CO}, 0.009$ $\mathrm{NH}_{4} \mathrm{MO}_{7} \mathrm{O}_{24} .4 \mathrm{H}_{2} \mathrm{O}, 0.054 \mathrm{H}_{3} \mathrm{BO}_{3}, 0.222 \mathrm{ZnSO}_{4} .7 \mathrm{H}_{2} \mathrm{O}$, $0.058 \mathrm{CuSO}_{4} \cdot 5 \mathrm{H}_{2} \mathrm{O}$ and $0.137 \mathrm{MnCl}_{2} \cdot 4 \mathrm{H}_{2} \mathrm{O}$. The nutrient solution was applied every week after seedling emergence. A volume of $15 \mathrm{~mL}$ of a solution containing $0.27 \mathrm{~g} \mathrm{~L}^{-1} \mathrm{FeSO}_{4} .7 \mathrm{H}_{2} \mathrm{O}$ and $0.37 \mathrm{~g} \mathrm{~L}^{-1}$ EDTA disodium was also applied after seedling emergence and repeated weakly.

The treatments were performed on plants grown in Si-deficient soil and sprayed with the following: (i) deionized water (control), (ii) $0.4 \mathrm{~g} \mathrm{~L}^{-1} \mathrm{ASM}$ (Bion $500 \mathrm{WG}$, Syngenta Crop Protection Inc., São Paulo, Brazil) and 
(iii) 2 mM JA (Sigma-Aldrich, São Paulo, Brazil) 24 h before inoculation with $P$. pachyrhizi. The fourth treatment consisted of plants grown in soil amended with calcium silicate. Deionized water as well as the solutions of ASM and JA were sprayed on the adaxial and abaxial leaf blades of each plant until runoff using a VL Airbrush atomizer (Paasche Air-brush Co., Chicago, IL, USA). Gelatin 1\% $(\mathrm{w} / \mathrm{v})$ was added to the sterile water to aid conidial adhesion to the leaf blades. Each plant received $25 \mathrm{~mL}$ of deionized water as well as the solutions of ASM and JA.

\section{Inoculation of plants with Phakopsora pachyrhizi}

Soybean plants at V6 growth stage (FeHr and CAVIness, 1977 ) were inoculated with a suspension of urediniospores of a monopustular isolate of $P$. pachyrhizi $\left(1 \times 10^{5}\right.$ urediniospores $\left.\mathrm{mL}^{-1}\right) 24$ hours after the spray of deionized water, ASM and JA. The isolate was previously multiplied in plants of the cultivar MG/BR 46 (Conquista). A total of $100 \mu \mathrm{L}$ of inoculum was transferred to 10 Petri dishes containing potato-dextrose-agar media and homogeneously distributed on each dish using a Drigalsky glass stick. Petri dishes were kept in complete darkness in a growth chamber at $25^{\circ} \mathrm{C}$. After 24 hours, lactophenol was added to the plates to stop urediniospore germination. One hundred urediniospores were examined, which were considered germinated when the germ tube was longer than its diameter. Urediniospore germination was observed under a light microscope (Carl Zeiss Axio Imager A1) at $400 \mathrm{x}$ magnification. A total of 100 urediniospores were randomly evaluated from each Petri dish to calculate the percentage of germination, which was found to be $89 \pm 3 \%$. After inoculation, the plants remained in a mist chamber at a temperature of $24 \pm 2{ }^{\circ} \mathrm{C}$ and relative humidity of $90 \pm 5 \%$ for $24 \mathrm{~h}$ in the absence of light. After this period, the plants were transferred to a plastic mist growth chamber inside a greenhouse for the duration of the experiments. The temperature inside the plastic mist growth ranged from $28 \pm 2{ }^{\circ} \mathrm{C}$ (day) to $20 \pm 2{ }^{\circ} \mathrm{C}$ (night). The relative humidity was maintained at $92 \pm 3 \%$ using a misting system in which nozzles (model NEB-100; KGF Company, São Paulo, Brazil) sprayed mist every 30 minutes above the plant canopy. Relative humidity and temperature were measured with a thermo-hygrograph (TH- 508, Impac, Brazil).

\section{Assessment of Asian soybean rust severity}

The severity of ASR was evaluated on the fourth, fifth and sixth leaves of each plant at V6 growth stage (Fehr and Caviness, 1977) per replication of each treatment at 18 days after inoculation (dai) according to the symptoms scale proposed by Godor et al. (2006).

\section{Determination of foliar silicon concentration}

After the experiment, all leaves from each plant, replication and treatment were collected, washed in deionized water, dried for 72 hours at $65{ }^{\circ} \mathrm{C}$ and ground to pass through a 40 mesh screen with a Thomas-Wiley mill. The foliar Si concentration was determined according to Dallagnol et al. (2011). Dried leaf tissue was digested with a nitric-perchloric solution $(3: 1, \mathrm{v} / \mathrm{v})$ and the concentration of $\mathrm{Ca}$ was determined by atomic absorption spectrophotometry.

\section{Determination of chitinases, $\beta$-1,3-glucanases, peroxidases, polyphenoloxidases and phenylalanine ammonia-lyases activities}

The trifoliate leaves at stages V3 and V4 (FeHr and CAviness, 1977) of plants inoculated or non-inoculated with $P$. pachyrhizi for the replications of each treatment were collected to determine the activities of chitinases (CHI, EC 3.2.1.14), $\beta$-1,3-glucanases (GLU, EC 3.2.1.39), peroxidases (POX, EC 1.11.1.7), polyphenoloxidases (PPO, EC 1.10.3.1) and phenylalanine ammonia-lyases (PAL, EC 4.3.1.5) at 24, 48, 72 and 141 hours after inoculation (hai). The collected leaves were placed in aluminum foil, frozen in liquid nitrogen and stored at $-80{ }^{\circ} \mathrm{C}$ until analysis.

For the extracts used in the determinations of $\mathrm{CHI}$ and GLU activities, $0.3 \mathrm{~g}$ of leaf tissue was powdered in liquid nitrogen in a mortar with the addition of $2 \%$ polyvinylpyrrolidone (PVP) w/v. The powder obtained was homogenized in $2 \mathrm{~mL} 50 \mathrm{mM}$ sodium phosphate $(\mathrm{pH}$ 6.5) containing $1 \mathrm{mM}$ phenylmethylsulfonyl fluoride (PMSF). The homogenate was centrifuged at $20,000 \mathrm{~g}$ for 25 minutes at $4{ }^{\circ} \mathrm{C}$ and the supernatant was used as extract for enzyme determination. The activity of CHI was determined by the method of ROBERTs and Selitrennikoff (1988) modified by Harman et al. (1993). The reaction was initiated by addition of $20 \mathrm{~mL}$ aliquots of the supernatant to a mixture of $470 \mathrm{~mL}$ of $50 \mathrm{mM}$ sodium acetate $(\mathrm{pH} 5.0)$ and $10 \mathrm{~mL}$ of the substrate $p$-nitrophenyl- $\beta$-DN-N -diacetylchitobiose (Sigma-Aldrich, São Paulo, Brazil) at a concentration of $2 \mathrm{mg} \mathrm{mL}^{-1}$. The reaction mixture was incubated in a water bath at $37^{\circ} \mathrm{C}$ for 2 hours. The reaction was stopped by addition of $500 \mu \mathrm{L} 0.2 \mathrm{M}$ sodium carbonate. In control samples, only the sodium carbonate was added after adding the extract to the reaction mixture and the samples were incubated in a water bath at $37^{\circ} \mathrm{C}$ for 2 hours. The absorbance of the final product was determined at $410 \mathrm{~nm}$ in a spectrophotometer (Evolution 60, Thermo Scientific, Waltham, MA, USA). The molar extinction 
coefficient of $7 \times 10^{4} \mathrm{mM}^{-1} \mathrm{~cm}^{-1}$ was used to calculate CHI activity, which was expressed as $\mu$ moles of $p$-nitrophenyl produced per minute per mg of protein. The GLU activity was determined as described by Lever (1972). The reaction was initiated by addition of $20 \mu \mathrm{L}$ aliquots of the supernatant to a mixture of $230 \mu \mathrm{L}$ of $100 \mathrm{mM}$ sodium acetate $(\mathrm{pH} 5.0)$ and $250 \mu \mathrm{L}$ of the substrate laminarin (Sigma-Aldrich, São Paulo, Brazil) in the concentration of $4 \mathrm{mg} \mathrm{mL}{ }^{-1}$. The reaction mixture was incubated in a water bath for 30 minutes at $45^{\circ} \mathrm{C}$. After the incubation period, the amount of reducing sugars was determined by adding $250 \mu \mathrm{L}$ of dinitrosalicylic acid to the mixture, followed by incubation in a water bath for 15 minutes at $100^{\circ} \mathrm{C}$. The reaction was stopped by cooling the samples in an ice bath to the temperature of $30^{\circ} \mathrm{C}$. In control samples, the reaction mixture was the same, except that the plant extract was added after heating the mixture at $100^{\circ} \mathrm{C}$. The absorbance was measured at $540 \mathrm{~nm}$ and GLU activity was expressed in absorbance units per minute per mg of protein.

To obtain the extracts used for determination of POX and PPO activities, $0.3 \mathrm{~g}$ of leaf tissue was powdered in liquid nitrogen in a mortar with addition of $2 \%$ PVP (w/v). The powder obtained was homogenized in $2 \mathrm{~mL} 100 \mathrm{mM}$ potassium phosphate ( $\mathrm{pH}$ 6.8) containing $1 \mathrm{mM}$ PMSF and $0.1 \mathrm{mM}$ ethylenediaminetetraacetic acid (EDTA). The homogenate was centrifuged at $1,200 \mathrm{~g}$ for 15 minutes at $4{ }^{\circ} \mathrm{C}$ and the supernatant was used for enzyme determination. POX and PPO activities were determined by the oxidation of pyrogallol according to the method of Kar and Mishra (1976). For POX activity, an aliquot of $100 \mu \mathrm{L}$ of the extract was added to a mixture of $475 \mu \mathrm{L}$ distilled water, $375 \mu \mathrm{L} 100 \mathrm{mM}$ potassium phosphate $(\mathrm{pH}$ 6.8), $300 \mu \mathrm{L} 100 \mathrm{mM}$ pyrogallol and $300 \mu \mathrm{L} 100 \mathrm{mM}$ hydrogen peroxide. For PPO activity, the mixture was composed of $100 \mu \mathrm{L}$ of the extract, $475 \mu \mathrm{L}$ distilled water, $375 \mu \mathrm{L} 100 \mathrm{mM}$ potassium phosphate (pH 6.8) and $300 \mu \mathrm{L} 100 \mathrm{mM}$ pyrogallol. The absorbance was measured at $420 \mathrm{~nm}$ in a spectrophotometer every 10 second for 1 minute after addition of the extract to the mixture. The molar extinction coefficient of $2.47 \mathrm{mM}^{-1} \mathrm{~cm}^{-1}$ was used to calculate the POX and PPO activities (Chance and MaEhley, 1955), which were expressed as mol of purpurogallin produced per minute per $\mathrm{mg}$ of protein. Throughout the process, the reaction tubes were covered with aluminum foil to protect the mixture from oxidation by light.

To obtain the extract to determine the PAL activity, $0.3 \mathrm{~g}$ of leaf tissue was powdered in liquid nitrogen in a mortar with the addition of $2 \%$ PVP $(w / v)$. The powder obtained was homogenized in $2 \mathrm{~mL} 50 \mathrm{mM}$ sodium borate $(\mathrm{pH} 8.7)$ containing $5 \mathrm{mM} \beta$-mercaptoethanol and $1 \mathrm{mM}$ EDTA. The mixture was centrifuged three times at $20,000 \mathrm{~g}$ for 30 minutes. The supernatant was used as substrate to determine the PAL activity. The reaction was initiated by adding $0.25 \mathrm{~mL}$ of the extract to a mixture containing $1 \mathrm{~mL} 0.1 \mathrm{M}$ sodium borate $(\mathrm{pH} 8.7)$ and $0.5 \mathrm{~mL} 20 \mathrm{mM} \mathrm{L}$-phenylalanine. The reaction mixture was incubated in a water bath at $30^{\circ} \mathrm{C}$ for $1 \mathrm{~h}$. In control samples, the extract was replaced by $1 \mathrm{~mL}$ sodium borate buffer. The reaction was interrupted by addition of $33 \mu \mathrm{L} 6 \mathrm{M} \mathrm{HCl}$. The absorbance of the derivatives of trans-cinnamic acid was measured in a spectrophotometer at $290 \mathrm{~nm}$ and the molar extinction coefficient of $10^{4} \mathrm{mM}^{-1} \mathrm{~cm}^{-1}$ (ZuCKER, 1965) was used to calculate the PAL activity, which was expressed in $\mu$ mol. $\mathrm{min}^{-1} . \mathrm{mg}^{-1}$ protein.

All enzyme determinations were performed in triplicate. The protein concentration in each sample was determined according to the method of BRADFORD (1976).

\section{Experimental design and statistical analysis}

For the assessment of ASR severity, the experiment was arranged in a completely randomized design with four treatments and ten replications. A $4 \times 2$ factorial experiment, consisting of four treatments and plants that were non-inoculated or inoculated with $P$. pachyrhizi, was arranged in a completely randomized design with twelve replications for the determination of enzyme activities. Each experimental unit consisted of one plastic pot with two plants. The experiment was repeated twice. Data from ASR severity were analyzed by analysis of variance (ANOVA) and the means of the treatments were compared by Tukey's test $(\mathrm{p} \leq 0.05)$ using SAS (version 6.12; SAS Institute, Inc., Cary, NC). For each enzyme studied, means from the non-inoculated and inoculated plants for each treatment at each evaluation time were compared by the $t$-test $(\mathrm{p} \leq 0.05)$ using SAS.

\section{RESULTS}

\section{Asian soybean rust severity}

The final ASR severity was significantly reduced on the leaves of plants sprayed with ASM or grown in soil amended with calcium silicate in comparison to plants sprayed with JA or deionized water (Figure 1).

\section{Silicon concentration in leaf tissue}

The Si concentration in leaf tissue of plants grown in soil amended with calcium silicate was significantly higher (2.6 g per kg of dry weight) compared to plants sprayed with ASM, JA and deionized water $(0.60,0.43$ and $0.51 \mathrm{~g}$ per kg of dry weight, respectively). There were no significant difference among the treatments ASM, JA and 
deionized water. The Si concentration in leaf tissue showed a similar trend for the treatments as determined in a preliminary experiment (data not shown).

\section{Enzyme activities}

For non-inoculated plants sprayed with deionized water, $\mathrm{CHI}$ activity increased from 24 to 72 hai and decreased at 141 hai (Figure 2a). For inoculated plants, $\mathrm{CHI}$ activity increased from 24 to 48 hai, decreased at 72 hai and increased thereafter (Figure 2a). The CHI activity for non-inoculated plants sprayed with ASM increased from 48 to 72 hai and decreased thereafter (Figure 2b). For inoculated plants sprayed with ASM, CHI activity increased from 24 to 48 hai, decreased at 72 hai and remained constant thereafter (Figure 2b). For non-inoculated plants sprayed with JA, CHI activity increased from 24 to 48 hai and then remained constant (Figure 2c). For inoculated plants, $\mathrm{CHI}$ activity increased from 24 to 48 hai and decreased at 72 hai, after which the activity remained constant (Figure 2c). For non-inoculated and inoculated plants grown in soil amended with calcium silicate, $\mathrm{CHI}$ activity increased from 24 to 48 hai (Figure $2 \mathrm{~d}$ ). In the non-inoculated plants, $\mathrm{CHI}$ activity decreased at 72 hai and remained constant thereafter (Figure 2d). For inoculated plants, CHI activity increased at 72 hai and then remained constant thereafter (Figure 2d). Significant differences between non-inoculated and inoculated plants sprayed with deionized water or sprayed with ASM occurred at 72 hai, at 24 and 72 hai for JA spray and at 141 hai when grown in soil amended with calcium silicate (Figure 2a,b,d).

For non-inoculated plants sprayed with deionized water, GLU activity increased from 24 to 48 hai and decreased thereafter (Figure 3a). For inoculated plants, GLU activity increased from 24 to 48 hai and then remained constant (Figure 3a). The GLU activity for non-inoculated plants sprayed with ASM increased at 48 hai, decreased at 72 hai and increased at 141 hai (Figure 3b). For inoculated plants sprayed with ASM, GLU activity increased from 24 to 48 hai and remained constant thereafter (Figure 3b). For non-inoculated plants sprayed with JA, GLU activity was constant for all sampling times (Figure 3c). For inoculated plants, GLU activity increased from 24 to 48 hai, decreased at 72 hai and increased at 141 hai (Figure 3c). The GLU activity for non-inoculated plants grown in soil amended with calcium silicate decreased from 24 to 48 hai and increased until 141 hai (Figure 3d). For inoculated plants, GLU activity increased from 24 to 48 hai and decreased until 141 hai (Figure 3d). Significant differences between non-inoculated and inoculated plants sprayed with deionized water occurred at 24, 48 and 141 hai and for those sprayed with ASM treatment only at 72 hai (Figure 3a,b).
POX activity in non-inoculated and inoculated plants sprayed with deionized water showed the same tendency, but POX activity was lower for non-inoculated plants at 24 and 141 hai (Figure 4a). For non-inoculated and inoculated plants sprayed with ASM, POX activity increased from 24 to 48 hai, decreased at 72 hai and increased thereafter with the highest values occurring for non-inoculated plants (Figure 4b). Non-inoculated and inoculated plants sprayed with JA showed an increase in POX activity from 24 to 48 hai (Figure 4c). In the non-inoculated plants, POX activity decreased at both 72 and 141 hai (Figure 4c). For inoculated plants, POX activity increased at 72 hai and stayed high thereafter (Figure 4c). For non-inoculated plants grown in soil amended with calcium silicate, POX activity increased until 72 hai and remained constant thereafter (Figure 4d). For inoculated plants, POX activity increased from 24 to 48 hai, decreased at 72 hai and increased thereafter (Figure 4d). Significant differences between non-inoculated and inoculated plants sprayed with deionized water or grown in soil amended with calcium silicate occurred only at 141 hai (Figure 4a,d).

PPO activity in non-inoculated plants sprayed with water increased from 24 to 48 hai, decreased at 72 hai and increased thereafter (Figure 5a). For inoculated plants sprayed with water, PPO activity increased from 24 to 141 hai (Figure 5a). For non-inoculated plants sprayed with ASM, PPO activity increased from 24 to 48 hai, decreased at 72 hai and increased thereafter (Figure 5b). For inoculated plants sprayed with ASM, PPO activity increased from 24 to 48 hai, remained constant until 72 hai and increased at 141 hai (Figure 5b). For non-inoculated plants sprayed with JA, PPO activity increased until 72 hai and decreased at 141 hai (Figure 5c). For inoculated plants, PPO activity increased from 24 to 48 hai, decreased at 72 hai and increased thereafter (Figure $5 \mathrm{c}$ ). For

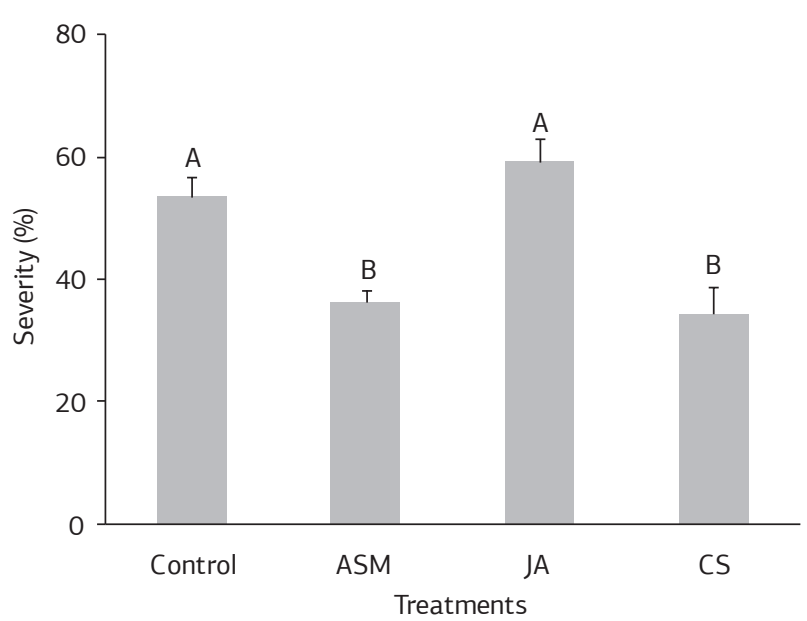

Figure 1. Final rust severity on leaves of soybean plants that received foliar application of deionized water (control), AcibenzolarS-Methyl and jasmonic acid or were grown in soil amended with calcium silicate. Means followed by the same letter are not significantly different $(\mathrm{p}=0.05)$ as determined by Tukey's test. Bar in each column represents the standard error of the mean. ASM: Acibenzolar-S-Methyl; JA: jasmonic acid; CS: calcium silicate. 


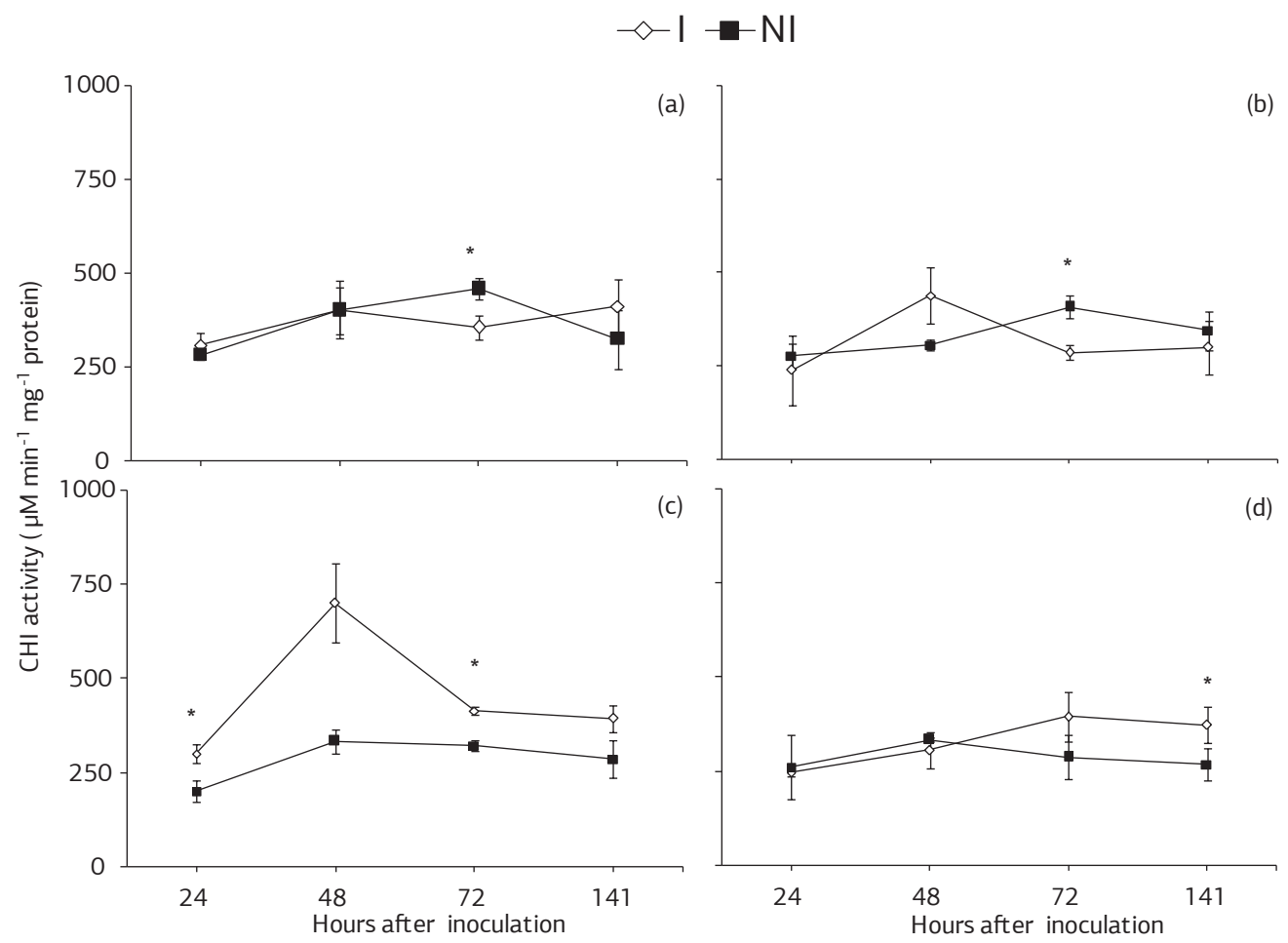

Figure 2. Activity of chitinases in leaf tissue of soybean plants inoculated or non-inoculated with Phakopsora pachyrhizi that previously received the spray of (a) deionized water, (b) Acibenzolar-S-Methyl, and (c) jasmonic acid or were grown in (d) soil amended with calcium silicate. Comparisons between inoculated and non-inoculated plants for each time point followed by an asterisk $\left(^{*}\right)$ are significantly different by the t-test. Bar at each point represents the standard error of the mean. CHI: chitinases; I: inoculated; NI: non-inoculated.

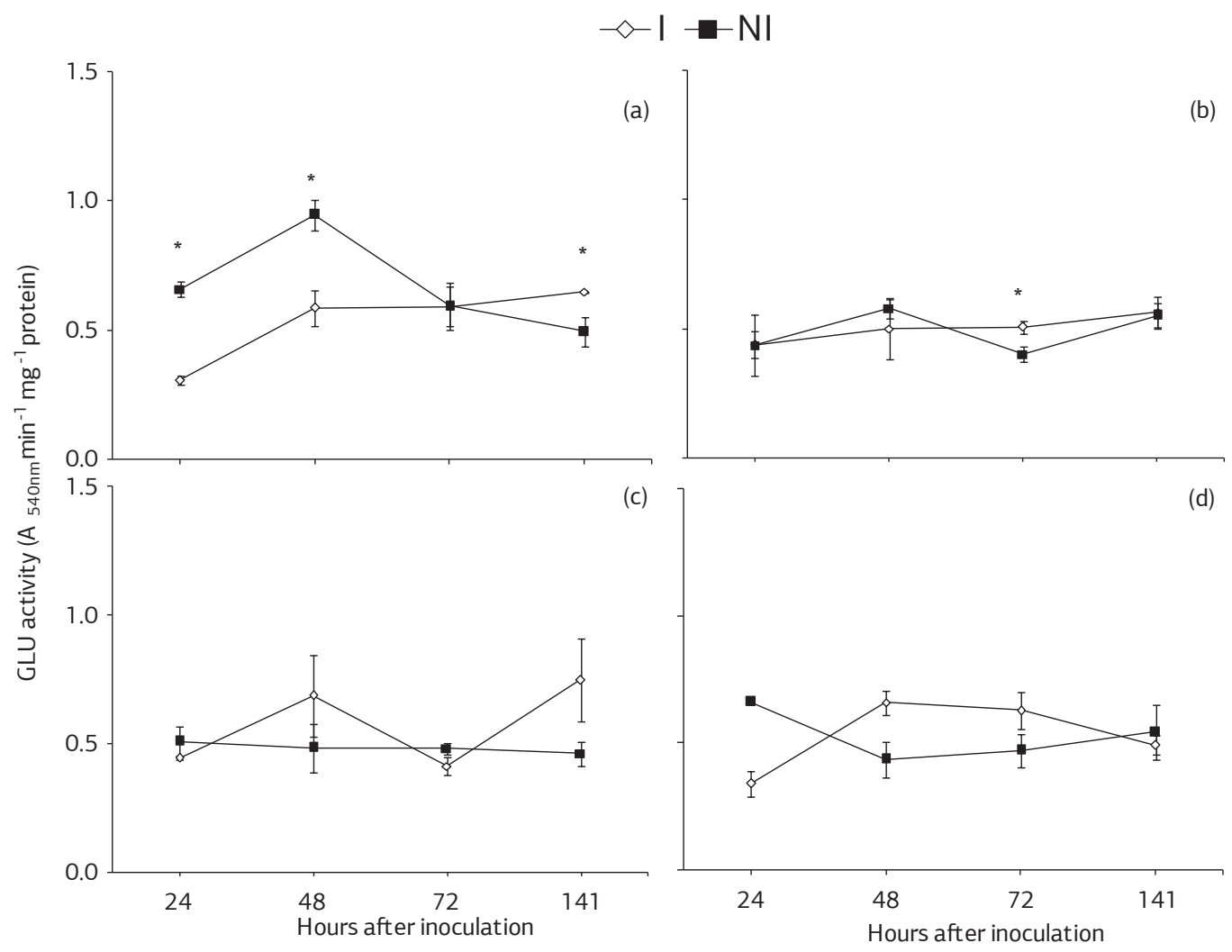

Figure 3. Activity of $\beta$-1,3-glucanases in leaf tissue of soybean plants inoculated or non-inoculated with Phakopsora pachyrhizi that previously received the spray of (a) deionized water, (b) Acibenzolar-S-Methyl, and (c) jasmonic acid or were grown in (d) soil amended with calcium silicate. Comparisons between inoculated and non-inoculated plants for each time point followed by an asterisk $\left(^{*}\right)$ are significantly different by the t-test. Bar at each point represents the standard error of the mean. GLU: $\beta$-1,3-glucanases; I: inoculated; NI: non-inoculated. 


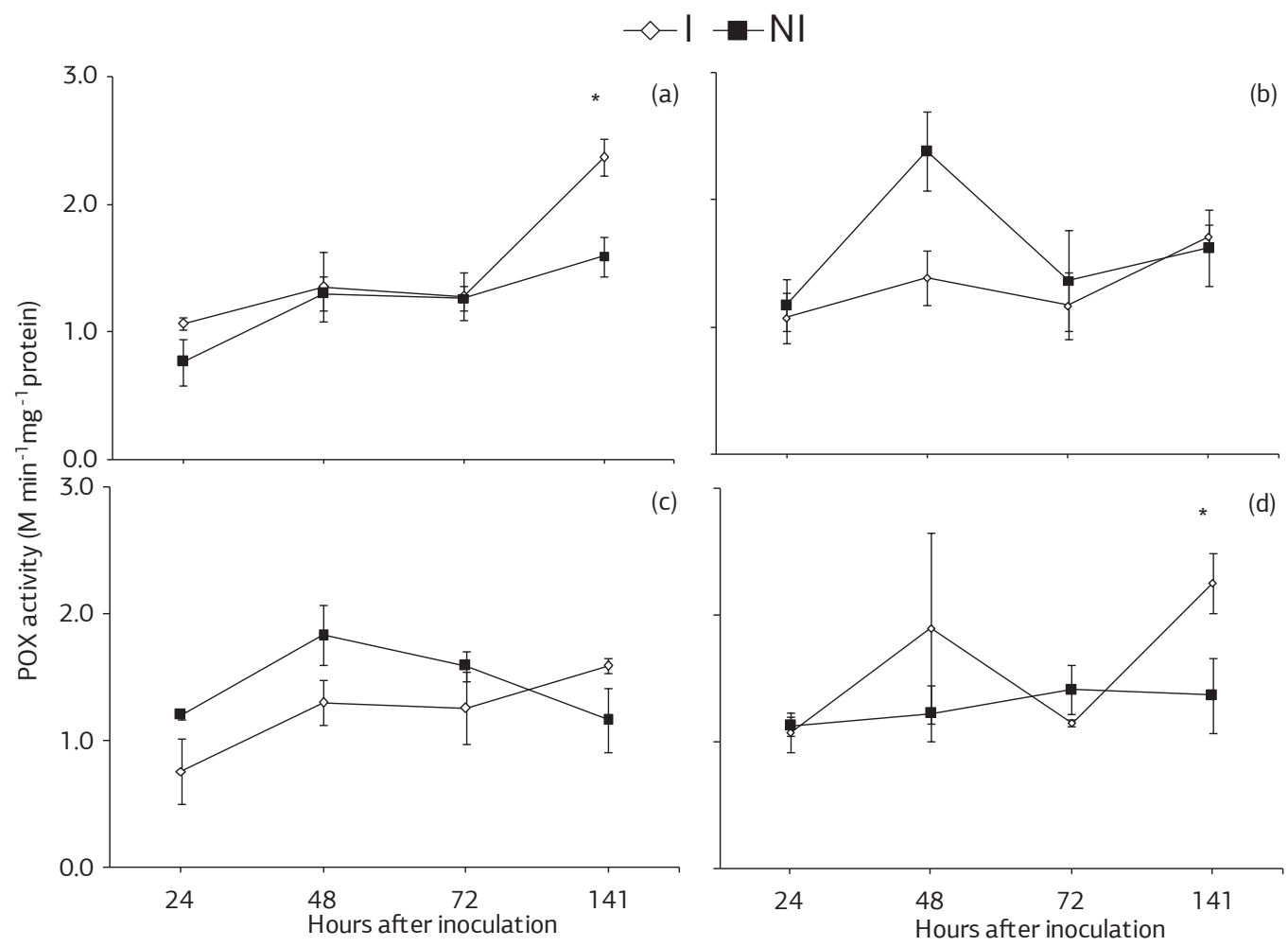

Figure 4. Activity of peroxidases in leaf tissue of soybean plants inoculated or non-inoculated with Phakopsora pachyrhizi that previously received the spray of (a) deionized water, (b) Acibenzolar-S-Methyl, and (c) jasmonic acid or were grown in (d) soil amended with calcium silicate. Comparisons between inoculated and non-inoculated plants for each time point followed by an asterisk $\left({ }^{*}\right)$ are significantly different by the t-test. Bar at each point represents the standard error of the mean. POX: peroxidases; I: inoculated; NI: non-inoculated.

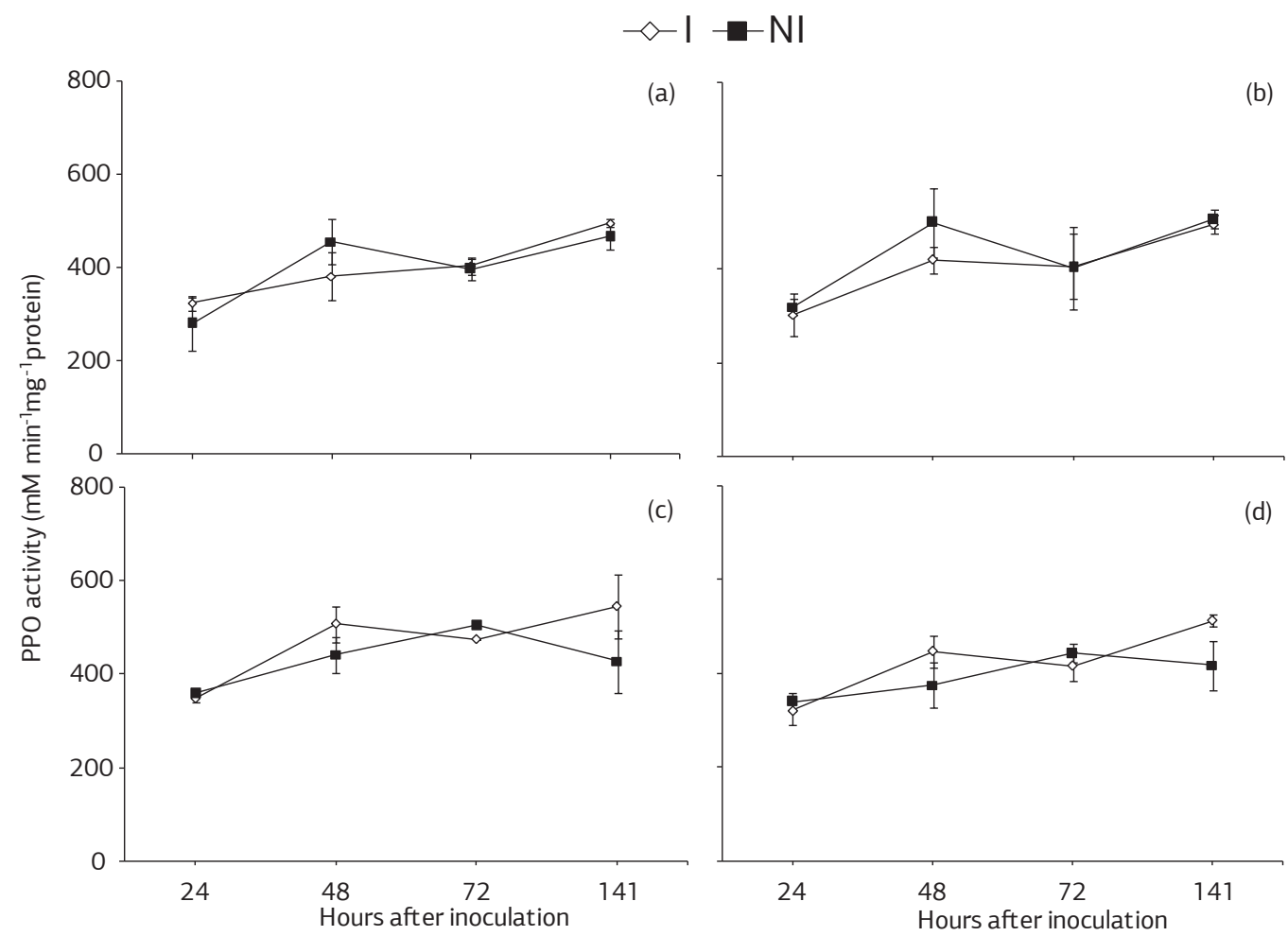

Figure 5. Activity of polyphenoloxidases in leaf tissue of soybean plants inoculated or non-inoculated with Phakopsora pachyrhizi that previously received the spray of (a) deionized water, (b) Acibenzolar-S-Methyl, and (c) jasmonic acid or were grown in (d) soil amended with calcium silicate. Bar at each point represents the standard error of the mean. PPO: polyphenoloxidases; I: inoculated; NI: non-inoculated. 
non-inoculated plants grown in soil amended with calcium silicate, PPO activity increased until 72 hai and decreased at 141 hai (Figure 5d). For inoculated plants, PPO activity increased from 24 to 48 hai, decreased at 72 and increased at 141 hai (Figure 5d). There was no significant difference between non-inoculated and inoculated plants for any treatment (Figure 5a-d).

For non-inoculated plants sprayed with deionized water, PAL activity increased constantly from 24 to 72 hai and remained constant until 141 hai (Figure 6a). The PAL activity increased for inoculated plants sprayed with deionized water from 24 to 48 hai and decreased thereafter (Figure 6a). For non-inoculated plants sprayed with ASM, PAL activity increased from 24 to 48 hai, decreased at 72 hai and increased thereafter (Figure 6b). For inoculated plants sprayed with ASM, PAL activity increased constantly from 24 to 141 hai (Figure 6b). For non-inoculated plants sprayed with JA, PAL activity increased until 48 hai, decreased at 72 hai and remained constant thereafter (Figure 6c). For inoculated plants, PAL activity increased from 24 to 48 hai, decreased at 72 hai and increased thereafter (Figure 6c). For non-inoculated plants grown in soil amended with calcium silicate, PAL activity increased until 72 hai and decreased at 141 hai (Figure 6d). For inoculated plants, PAL activity increased from 24 to 48 hai, decreased at 72 hai and remained constant at 141 hai (Figure 6d).
Significant differences between non-inoculated and inoculated plants occurred only when they were sprayed with ASM at 72 and 141 hai (Figure 6b).

\section{DISCUSSION}

Even though many studies have investigated the soybea-P. pachyrhizi interaction, information concerning the biochemical events in response to inducers of resistance such as JA and ASM as well as Si application is, to the best of our knowledge, missing. In the present study, differential responses were observed in the ASR severity and the activity of defense enzymes depending on the inducer used or Si application. Soybean resistance to ASR was enhanced when plants were sprayed with ASM or grown in soil amended with calcium silicate.

The intensities of diseases in crops of economic importance such as barley, corn, cucumber, oats, rice, rye, soybean, sorghum, strawberry and wheat can be decrease by $\mathrm{Si}$ (DATNOFF et al., 2007). In the present study, the increase in the $\mathrm{Si}$ concentration in leaf tissue of soybean plants grown in soil amended with calcium silicate contributed to reduce the ASR severity. CRUz et al. (2012) reported that in leaflets of soybean plants supplied with Si and inoculated with P. pachyrbizi, uredia were smaller and fewer in number with

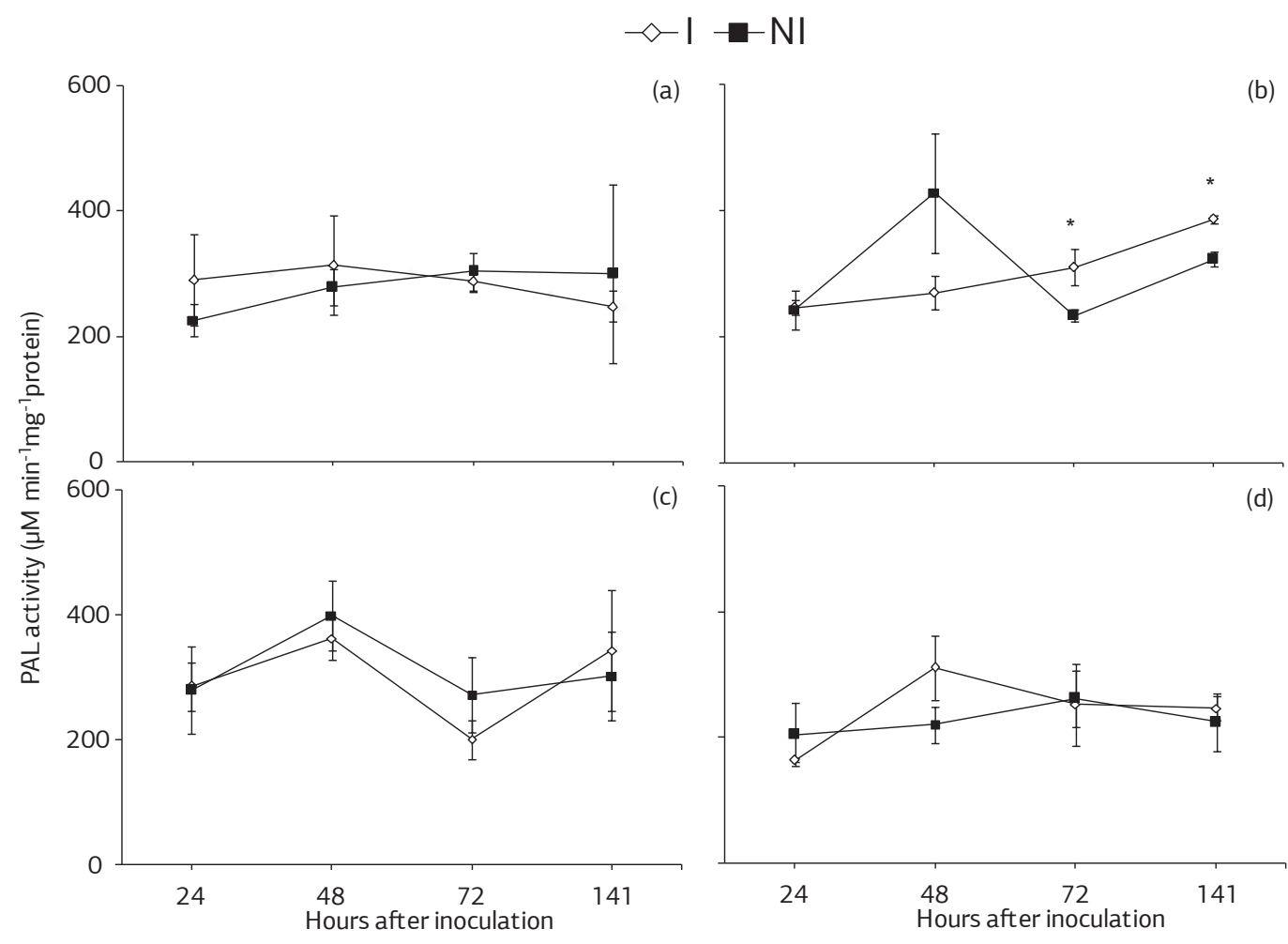

Figure 6. Activity of phenylalanine ammonia-lyases in leaf tissue of soybean plants inoculated or non-inoculated with Phakopsora pachyrhizi that previously received the spray of (a) deionized water, (b) Acibenzolar-S-Methyl, and (c) jasmonic acid or were grown in (d) soil amended with calcium silicate. Comparisons between inoculated and non-inoculated plants for each time point followed by an asterisk $\left(^{*}\right)$ are significantly different by the t-test. Bar at each point represents the standard error of the mean. PAL: phenylalanine ammonia-lyases; I: inoculated; NI: non-inoculated. 
reductions of 27,23 and $60 \%$ in the number of lesions, closed uredia and open uredia, respectively, in comparison to leaflets of plants non-supplied with Si. Lemes et al. (2011) reported reductions of 43 and 36\% of the area under ASR progress curve for plants grown in soil amended with $\mathrm{Si}$ and sprayed with potassium silicate, respectively. Reductions of $65 \%$ in the severity of ASR occurred with potassium silicate spray (RodRigues et al., 2009).

The CHI and GLU are enzymes that catalyze the hydrolysis of the carbohydrates chitin and $\beta$-1,3-glucan, respectively, which are found in the cell wall of several fungi and release oligosaccharides that may elicit host defense responses (Keen and Yoshikawa, 1983). In the present study, an increase in CHI activity occurred early in the onset of ASR symptoms for plants supplied with $\mathrm{Si}$, whereas GLU activity was enhanced only for plants sprayed with ASM. Thus, it is evident that the coexistence of these two hydrolytic enzymes is important for the restriction of colonization by $P$. pachyrhizi in soybean leaf tissue.

POX plays a role in the host defense response through the production of antimicrobial quantities of $\mathrm{H}_{2} \mathrm{O}_{2}$, in cell wall lignification or cross-linking with the cell wall proteins (Chittoor et al., 1999; Torres et al., 2006). In the present study, there was a trend toward increased POX activity in the early onset of ASR. However, the contribution of this enzyme to soybean resistance to ASR was inconclusive. In contrast, an increase in the amount of POX transcripts in plants of a rice cultivar susceptible to Pyricularia grisea and supplied with $\mathrm{Si}$ was reported by Datnoff et al. (2007). A relationship between PPO activity and soybean resistance to $P$. pachyrhizi infection was not found in the present study. Rice and cucumber plants supplied with $\mathrm{Si}$ and inoculated with Bipolaris oryzae and Podosphaera xantii, respectively, showed an increase in the activities of POX and CHI (Dallagnol et al., 2011; Liang et al. 2005).

Pereira et al. (2009) reported that soybean plants sprayed with ASM showed reduced symptoms of ASR without any contribution of CHI, GLU, POX, PPO, PAL and lypoxygenase. However, in the present study, plants sprayed with ASM showed an increase in PAL activity at 72 and 141 hai and GLU activity at 72 hai. Interestingly, among all of the enzymes studied, only PAL showed a trend toward increased activity in plants sprayed with ASM. The $L$-phenylalanine is converted to trans-cinnamic acid by PAL, which results in the synthesis of various phenolic compounds and phytoalexins and ultimately lignin (CAMPBelL and SEDEROFF, 1996). Therefore, the high level of PAL activity in the leaves of plants sprayed with ASM suggests the importance of the phenylpropanoid pathway for soybean resistance against infection by $P$. pachyrhizi. Increased PAL activity as a result of ASM spray was also reported for the interactions cowpea-Fusarium oxysporum f.sp. tracheiphilum (Rodrigues et al., 2006) and banana-Fusarium oxysporum f.sp. cubense (Saravanan et al., 2004). According to Liang et al. (2005), strong PAL activity was dependent on the level of basal resistance of cucumber cultivars to $P$. xanthii.

The results of this study reinforce the reports in the literature showing that the symptoms of ASR can be ameliorated through ASM spray and supplying $\mathrm{Si}$ to the plants and add the novel information that this process involves the participation of the enzymes CHI, PAL and GLU.

\section{ACKNOWLEDGEMENTS}

F.A. Rodrigues, E.G. Barros and M.A. Moreira thank Conselho Nacional de Desenvolvimento Cientifico e Tecnológico (CNPq) for their fellowship. M.F Cruz was supported by Coordenação de Aperfeiçoamento de Pessoal de Nivel Superior (CAPES). The authors would like to express their appreciation to Prof. G. H. Korndörfer for silicon analysis. The authors are grateful to Syngenta Crop Protection Ltda and Harsco Minerais Ltda for providing the Bion ${ }^{\circledR}$ and AgroSilício ${ }^{\circledR}$, respectively. This study was supported by grants from CAPES, CNPq and Fundação de Amparo à Pesquisa do Estado de Minas Gerais (FAPEMIG).

\section{REFERENCES}

ACHUO, E.A.; AUDENAERT, K.; MEZIANE, H.; HÖFTE M. The salicylic acid-dependent defence pathway is effective against different pathogens in tomato and tobacco. Plant Pathology, v.53, p.65-72, 2004. DOI: 10.1111/j.1365-3059.2004.00947.x

BRADFORD, M.M. A rapid and sensitive method for the quantitation of microgram quantities of protein utilizing the principle of protein-dye binding. Analytical Biochemistry, v.72, p.248-254, 1976. DOI: 10.1006/abio.1976.9999

BRUNINGS, A.M.; DATNOFF, L.E.; MA, J.F.; MITANI, N.; NAGAMURA, Y.; RATHINASABAPATHI, B.; KIRST, M. Differential gene expression of rice in response to silicon and rice blast fungus Magnaporthe oryzae. Annals of Applied Biology, v.155, p.161-170, 2009. DOI: 10.1111/j.1744-7348.2009.00347.x

CAMPBELL, M.M.; SEDEROFF R.R. Variation in lignin content and composition. Plant Physiology, v.110, p.3-13, 1996.

CHANCE, B.; MAEHLEY, A.C. Assay of catalases and peroxidases. Methods in Enzymology, v.2, p.764-775, 1955. DOI: 10.1016/ S0076-6879(55)02300-8

CHITTOOR, J.M.; LEACH, J.E.; WHITE, F.F. Induction of peroxidase during defense against pathogens. In: PathogenesisRelated Proteins in Plants. Boca Raton, FL, USA: CRC Press, 1999, p.171-193.

CRUZ, M.F.A.; SILVA, L.F.; RODRIGUES, F.A.; ARAUJO, J.M.; BARROS, E.G. Silício no processo infeccioso de Phakopsora 
pachyrhizi em folíolos de plantas de soja. Pesquisa Agropecuária Brasileira, v.47, p.142-145, 2012. DOI: 10.1590/S0100204X2012000100020

DALLAGNOL, L.J.; RODRIGUES, F.A.; DAMATTA, F.M. MIELLI, M.V.B.; PEREIRA, S.C. Deficiency in silicon uptake affects cytological, physiological, and biochemical events in the riceBipolaris oryzae interaction. Phytopathology, v.101, p.92-104, 2011.

DATNOFF L.E.; RODRIGUES F.A.; SEEBOLD K. Silicon and Plant Disease. In: Mineral Nutrition and Plant Disease. The American Phytopathological Society: St. Paul, MN, 2007, p.233-246.

DONG, X. SA, JA, ethylene, and disease resistance in plants. Current Opinion in Plant Biology, v.1, p.316-323, 1998. DOI: $10.1016 / 1369-5266(88) 80053-0$

FEHR, W.R.; CAVINESS, C.E. Stages of soybean development. Ames: Iowa State University Press, 1977.

GODOY, C.V.; KOGA, L.J.; CANTERI, M.G. Diagrammatic scale for assessment of soybean rust severity. Fitopatologia Brasileira, v.31, p.63-68, 2006. DOI: 10.1590/S0100-41582006000100011

HALIM, V.A.; ESCHEN-LIPPOLD, L.; ALTMANN, S.; BIRSCHWILKS, M.; SCHEEL, D.; ROSAHL, S. Salicylic acid is important for basal defense of Solanum tuberosum against Phytophthora infestans. Molecular Plant Microbe Interaction, v.20, p.1346-1352, 2007. DOI: 10.1094/MPMI-20-11-1346

HARMAN, G.E.; HAYES C.K.; LORITO, M.; BROADWAY, R.M.; PIETRO, A.; PETERBAUER C.; TRONSMO, A. Chitinolytic enzymes of Trichoderma harzianum: purification of chitobiosidase and endochitinase. Phytopathology, v.83, p.313318, 1993.

KAR, M.; MISHRA, D. Catalase, peroxidase, and polyphenoloxidase activities during rice leaf senescence. Plant Physiology, v.57, p.315319, 1976. DOI: $10.1104 /$ pp.57.2.315

KEEN, N.T.; YOSHIKAWA, M. $\beta$-1,3-endoglucanase from soybean releases elicitor active carbohydrates from fungus cell walls. Plant Physiology, v.71, p.460-465, 1983.

LEMES, E.M.; MACKOWIAK, C.L.; BLOUNT, A.; MAROIS, J.J.; WRIGHT, D.L.; COELHO, L.; DATNOFF, L.E. Effects of silicon applications on soybean rust development under greenhouse and field conditions. Plant Disease, v.95, p.317-324, 2011. DOI: 10.1094/PDIS-07-10-0500

LEVER, M. A new reaction for colorimetric determination of carbohydrates. Analytical Biochemistry, v. 47, p.273-279, 1972. DOI: 10.1016/0003-2697(72)90301-6

LIANG, Y.C.; SUN, W.C.; SI, J.; RÖMHELD, V. Effects of foliar and root applied silicon on the enhancement of induced resistance to powdery mildew in Cucumis sativus. Plant Pathology, v.54, p.678-685, 2005. DOI: 10.1111/j.1365-3059.2005.01246.x

LI, X.; ESKER, P.D.; PAN, Z.; DIAS, A.P.; XUE, L.; YANG, X.B. The uniqueness of the soybean rust pathosystem: an improved understanding of the risk in different regions of the world. Plant Disease, v.94, p.796-806, 2010. DOI: 10.1094/PDIS-94-7-0796
OGLE, H.J.; BYTH, D.E.; MCLEAN, R. Effect of rust (Phakopsora pachyrhizi) on soybean yield and quality in southeastern Queensland. Australian Journal of Agricultural Research, v.30, p.883-893, 1979. DOI: 10.1071/AR9790883

PEREIRA, S.C.; RODRIGUES, F.A.; CARRÉ-MISSIO, V.; OLIVEIRA, M.G.A.; ZAMBOLIM, L. Aplicação foliar de silício na resistência da soja à ferrugem e na atividade de enzimas de defesa. Tropical Plant Pathology, v.34, p.164-170, 2009. DOI: 10.1590/ S1982-56762009000300005

RESENDE, R.S.; RODRIGUES, F.A.; SOARES, J.M.; CASELA, C.R. Influence of silicon on some components of resistance to anthracnose in susceptible and resistant sorghum lines. European Journal of Plant Pathology, v.124, p.533-541, 2009. DOI: $10.1007 / \mathrm{s} 10658-009-9430-6$

ROBERTS, W.K.; SELITRENNIKOFF, C.P. Plant and bacterial chitinases differ in antifungal activity. Journal of General Microbiology, v.134, p.169-176, 1988. DOI: 10.1099/00221287134-1-169

RODRIGUES, A.A.C.; BEZERRA NETO, E.; COELHO, R.S.B. Indução de resistência a Fusarium oxysporum f.sp. tracheiphilum em caupi: eficiência de indutores abióticos e atividade enzimática elicitada. Fitopatologia Brasileira, v.31, p.492-499, 2006. DOI: 10.1590/S0100-41582006000500009

RODRIGUES, F.A.; DUARTE, H.S.S.; DOMICIANO, G.P.; SOUZA, C.A.; KORNDÖRFER, G.H.; ZAMBOLIM L. Foliar application of potassium silicate on the control of soybean rust. Australasian Plant Pathology, v.38, p.366-372, 2009. DOI: 10.1071/AP09010

SARAVANAN, T.; BHASKARAN, R.; MUTHUSAMY, M. Pseudomonas fluorescens induced enzymological changes in banana roots (cv. Rasthali) against Fusarium wilt. Plant Pathology Journal, v.3, p.72-80, 2004.

SCHWEIZER, P.; BUCHALA, A.; DUDLER, R.; MÉTRAUX, J.P. Induced systemic resistance in wounded rice plants. The Plant Journal, v.14, p.475-481, 1998. DOI: 10.1046/j.1365313X.1998.00141.x

SHETTY, R.; JENSEN, B.; SHETTY, N.P.; HANSEN, C.W.; STARKEY, K.R.; JORGENSEN, H.J.L. Silicon induced resistance against powdery mildew of roses caused by Podosphaera pannosa. Plant Pathology, v.61, p.120-131, 2012. DOI: 10.1111/j.13653059.2011.02493.x

SINCLAIR, J.B.; HARTMAN, G.L. Soybean Rust. In: Compendium of Soybean Diseases. The American Phytopathological Society: St. Paul, MN, 1999. p.25-26.

TORRES, M.A.; JONES, J.D.G.; DANGL J.L. Reactive oxygen species signaling in response to pathogens. Plant Physiology, v.141, p.373-378, 2006. DOI: 10.1104/pp.106.079467

YAMANAKA, N.; YAMAOKA, Y.; KATO, M.; LEMOS, N.G.; PASSIANOTTO, A.L.L.; SANTOS, J.V.M.; BENITEZ, E.R.; ABDELNOOR, R.V.; SOARES, R.M.; SUENAGA, K. Development of classification criteria for resistance to soybean rust and differences in virulence among Japanese and Brazilian 
rust populations. Tropical Plant Pathology, v.35, p.153-162, 2010. DOI: $10.1590 /$ S1982-56762010000300003

YORINORI, J.T.; PAIVA, W.M.; FREDERICK, R.D.; COSTAMILAN, L.M.; BERTAGNOLLI, P.F.; HARTMAN, G.E.; GODOY, C.V.; NUNES JÚNIOR, J. Epidemics of soybean rust (Phakopsora pachyrhizi) in Brazil and Paraguay from 2001 to 2003. Plant Disease, v.89, p.675-677, 2003. DOI: 10.1094/PD-89-0675
YOSHIDA, S.; OHINISHI, Y.; KITAGISHI, K. Chemical forms, mobility, and deposition of silicon in the rice plant. Soil Science and Plant Nutrition, v.8, p.107-111, 1962. DOI: 10.1080/00380768.1962.10430992

ZUCKER, M. Induction of phenylalanine deaminase by light and its relation to chlorogenic acid synthesis in potato tuber tissue. Plant Physiology, v.40, p.779-784, 1965. DOI: 10.1104/ pp.40.5.779 


\section{Bragantia, v.72, n.2, 2013}

No artigo científico "Inducers of resistance and silicon on the activity of defense enzymes in the soybean-Phakopsora pachyrhizi interaction", de autoria de Maria Fernanda Antunes da Cruz; Fabrício Ávila Rodrigues; Eleonora Rodrigues Polanco; Carmen Rosa da Silva Curvêlo; Kelly Juliane Telles Nascimento; Maurílio Alves Moreira; Everaldo Gonçalves Barros.

\section{Página 162}

\section{Onde se lê:}

Eleonora Rodrigues Polanco

\section{Leia-se:}

Leonora Rodriguez Polanco

\section{Pág. 168 - Figura 4}

\section{Onde se lê:}

Figure 4. Activity of peroxidases in leaf tissue of soybean plants inoculated or non-inoculated with Phakopsora pachyrhizi that previously received the spray of (a) deionized water, (b) Acibenzolar-S-Methyl, and (c) jasmonic acid or were grown in (d) soil amended with calcium silicate. Bar at each point represents the standard error of the mean. POX: peroxidases; I: inoculated; NI: non-inoculated.

\section{Leia-se:}

Figure 4. Activity of peroxidases in leaf tissue of soybean plants inoculated or non-inoculated with Phakopsora pachyrhizi that previously received the spray of (a) deionized water, (b) Acibenzolar-S-Methyl, and (c) jasmonic acid or were grown in (d) soil amended with calcium silicate. Comparisons between inoculated and non-inoculated plants for each time point followed by an asterisk $\left({ }^{*}\right)$ are significantly different by the t-test. Bar at each point represents the standard error of the mean. POX: peroxidases; I: inoculated; NI: non-inoculated. 